\title{
The Origin and Diversification of Plant Family Dipterocarpaceae
}

\author{
Mahi Bansal1, Shivaprakash K. Nagarajư ${ }^{2,3}$, Vandana Prasad1* \\ ${ }^{1}$ Terminal Cretaceous-Cenozoic Ecosystem Laboratory, Birbal Sahni Institute of Palaeosciences, Lucknow, India \\ ${ }^{2}$ Centre for Structural and Functional Genomics, Biology Department, Concordia University, Montreal, Canada \\ ${ }^{3}$ The Nature Conservancy Centre India (TNCIndia), New Delhi, Delhi, India \\ Email: *prasad.van@gmail.com
}

How to cite this paper: Bansal, M., Nagaraju, S.K. and Prasad, V. (2019) The Origin and Diversification of Plant Family Dipterocarpaceae. Open Journal of Geology, 9, 593-596.

https://doi.org/10.4236/ojg.2019.910050

Received: August 15, 2019

Accepted: September 20, 2019

Published: September 23, 2019

Copyright (c) 2019 by author(s) and Scientific Research Publishing Inc. This work is licensed under the Creative Commons Attribution International License (CC BY 4.0).

http://creativecommons.org/licenses/by/4.0/

\begin{abstract}
The Dipterocarpaceae plant family, that shows a disjunct distribution in Gondwanan continents and Southeast Asia, is a dominant constituent of the tropical rain forests of Southeast Asia. The high species diversity of Dipterocarpaceae in SE Asian rain forests suggests its origin from SE Asia. However, its fossil history is much younger, from Oligocene, from the region. Based on the pollen fossil records from the late Cretaceous-early Paleogene sedimentary sequences of Indian subcontinent and the contemporaneous distribution of its extant taxa, evolutionary history of Dipterocarpaceae has been traced. The study suggests a West Gondwanan origin for this family. Present study also provides first evidence of Dipterocarpaceae genus Vateriopsis (endemic in Seychelles) type fossil pollen record from the late Cretaceous and early Palaeogene sedimentary sequences of western Indian margin.
\end{abstract}

\section{Keywords}

Fossil, Vateriospis, Pollen, Cretaceous, Dipterocarpaceae

\section{Introduction}

Dipterocarpaceae, an economically important arborescent family distributed in SE Asian tropical regions, is important for the production of timber, camphor and resins. There exist a lot of opinions about its systematic classification [1]. The family is subdivided into three subfamilies: 1) Monotoideae, restricted to Africa, Madagascar and South America; 2) Pakaraimoideae, endemic to South America; 3) Dipterocarpoideae, distributed in SE Asia [2]. Except the two genera, Pseudomonotes and Marquesia, the representatives of Monotoideae distributed across Africa and Madagascar cultivate in seasonally dry forests. Whereas 
members of Pakaraimoideae and Dipterocarpoideae subfamilies prefer lowland rain forest. It has been found that various species of Dipterocarpoideae have the adaptability to seasonally wet and aseasonal perhumid tropical regions of SE Asia [1]. Due to more plasticity in the climatic adaptive nature, members of Dipterocarpoideae exhibit greater species diversity compared to the other two subfamilies. The family is disseminated across continents following a strict disjunct distribution pattern which raises a question of its place and time of origin. Dipterocarpoideae clade dominates in SE Asia and almost $80 \%$ of its diversity has been found to occur in wet forest of SE Asia particularly in Western Malaysia (Borneo), and hence SE Asia was considered to be its centre of origin [3]. There are two plausible hypotheses proposed for the evolutionary history and biogeography of the family Dipterocarpaceae. One hypothesis supports a SE Asian origin (Into India hypothesis). The other suggests a Gondwanan origin (Out of India hypothesis) [3]. In the present study, we are trying to assess both biogeographic hypotheses based on fossil data.

\section{Material and Method}

Studied samples were collected from three sites: 1) Late Cretaceous infratrappean bore core samples from Yeotmal region, Maharashtra; 2) Late Cretaceous intertrappean samples from Gowmukh area, Madhya Pradesh; 3) Early Palaeogene (Danian) samples from Gurha lignite mine, Bikaner region, Rajasthan. For comparison purposes, extant flower buds of Vateriopsis collected from Seychelles were acetolysed for pollen study and the extant pollen were compared with the fossil palynomorphs.

\section{Results}

The current study finds the presence of Vateriopsis type pollen fossil from the Upper Cretaceaous and Lower Palaeogene deposits of intertrappeans of central India and Bikaner Basin, Rajasthan, India, respectively. This study also documents the variety of Dipterocarpus type pollen fossils from the Upper Cretaceous of infratrappeans and intertrappeans of Maharashtra and Madhya Pradesh, central India, and the Lower Paleogene of Bikaner Basin, Rajasthan, western India.

\section{Discussion and Conclusion}

The Late Cretaceous Vateriopsis and Dipterocarpus type fossil pollen records suggest the Out of India hypothesis. Dipterocarpus type fossil pollen is recovered from the Indian Upper Cretaceous, the time when Indo-Seychelles plate was in surficial contact with Africa [4]. The distance between Asia and India during the Late Cretaceous was too large and could not facilitate the dispersal of the family. The presence of Vateriopsis type fossil pollen in Indian Lower Paleogene is the time just before the separation of Indo-Greater Somalaria from Seychelles [4]. The present distribution of Vateriopsis in Seychelles suggests its migration from 
India. Moreover, the presence of possible Dipterocarpus fossils from Africa [1] [5], a continent where only Monotes is found in the present day, also strongly indicates the diversification of the family on Gondwanan landmass. Our consent of Out of India hypothesis for Dipterocarpaceae dispersal in SE Asia is much more strengthened by the presence of polycadinene resin in the Upper Eocene of Mayanmar which was a part of Indian plate before its collision to Asia [6]. This suggests that the family might have migrated to Asia after the contact between India and Asia was established.

Furthermore the sharing of ectomycorrhizal symbiotic relation between Dipterocarpaceae and Sarcolaenaceae, a family endemic to Madagascar in present time, signifies that both families share a common ancestor [7]. The previously stated fact and the only Miocene fossil record of Sarcolaenaceae from Africa [8] imply that the diversification of the families should have occurred on the Gondwana landmass before the separation of Madagascar from India-Seychelles block.

\section{Acknowledgements}

The study is supported by the project MoES/P.O.(GeoSci.)/36/2014. This is a contribution to UNESCO-IUGS IGCP Project 679.

\section{Conflicts of Interest}

The authors declare no conflicts of interest regarding the publication of this paper.

\section{References}

[1] Maury-Lechon, G. and Curtet, L. (1998) Biogeography and Evolutionary Systematics of Dipterocarpaceae. In: Appanah, S. and Turnbull, J.M., Eds., A Review of Dipterocarps: Taxonomy, Ecology and Silviculture, Center for International Forestry Research, Indonesia, 5-44.

[2] Maguire, B., Ashton, P.S., De Zeeuw, C., Giannasi, D.E. and Niklas, K.J. (1977) Pakaraimoideae, Dipterocarpaceae of the Western Hemisphere. Taxon, 26, 341-385. https://doi.org/10.1002/j.1996-8175.1977.tb04186.x

[3] Kundu, S. (2008) A Synopsis of Dipterocarpaceae in Indian Subcontinent: Its Distribution and Endemism. Acta Botanica Hungarica, 50, 125-142. https://doi.org/10.1556/ABot.50.2008.1-2.9

[4] Chatterjee, S. and Scotese, C.R. (1999) The Breakup of Gondwana and the Evolution and Biogeography of the Indian Plate. Proceedings of Indian National Science Academy Part A, 65, 397-426.

[5] Shukla, A., Mehrotra, R.C. and Guleria, J.S. (2013) Emergence and Extinction of Dipterocarpaceae in Western India with Reference to Climate Change: Fossil Wood Evidences. Journal of Earth System Science, 122, 1373-1386. https://doi.org/10.1007/s12040-013-0341-8

[6] Suryendu, D., et al. (2011) Eocene Out-of-India Dispersal of Asian Dipterocarps. Review of Palaeobotany and Palynology, 166, 63-68. https://doi.org/10.1016/j.revpalbo.2011.05.002 
[7] Ducousso, M., et al. (2004) The Last Common Ancestor of Sarcolaenaceae and Asian Dipterocarp Trees Was Ectomycorrhizal before the India-Madagascar Separation, about 88 Million Years Ago. Molecular Ecology, 13, 231-236.

https://doi.org/10.1046/j.1365-294X.2003.02032.x

[8] Nilsson, S., Coetzee, J. and Grafström, E. (1996) On the Origin of the Sarcolaenaceae with Reference to Pollen Morphological Evidence. Grana, 35, 321-334. https://doi.org/10.1080/00173139609429091 